\title{
Singapore 2004
}

\author{
By Ron Holloway
}

Fall 2004 Issue of KINEMA

\section{SINGAPORE INTERNATIONAL FILM FESTIVAL 2004}

For nearly two decades, the Singapore International Film Festival (SIFF), the showcase of Southeast Asian cinema, has also served as a timely beacon for other key Asian film festivals. Pusan in Korea, Filmex in Tokyo, and Cinefan in New Delhi have benefited from Singapore, simply because SIFF was on the scene first and did all the spadework. Link all four festivals together, and the committed cineaste can easily anticipate Asian entries selected later for Cannes, Venice, Berlin, Montreal, and elsewhere. Its secret? The SIFF is independently operated under a quartet of film professionals (Geoffrey Malone, Philip Cheah, Lesley Ho, and Teo Swee Leng), who concentrate on quality Asian cinema. The Silver Screen Awards, inaugurated in 1991, are judged by a professional jury of peers. The Asian Films section a focuses on current trends, styles, and themes in the respective national cinemas. And Singapore happens to be the only festival on the circuit with a combined NETPAC-FIPRESCI Jury - coordinated by the Network for Promotion of Asian Cinema and the International Federation of Film Critics.

The $17^{\text {th }}$ SIFF (15 April to 1 May 2004) opened with Kim Ki-duk's Bom yeoreum gaeul gyeoul geurigo bom (Spring, Summer, Fall, Winter...and Spring, Korea-Germany), previously awarded the NETPAC Prize at Locarno. Set in a hermitage on an isolated island, Spring, Summer, Fall, Winter... and Spring comes across as a spiritual allegory rendered in stunning seasonal imagery. In this minimalist tale about two Buddhist monks, the older wisely leads the younger along the path of redemption after he has lost his way and committed murder. Kim himself plays the wayward monk at the crucial moment of his remorseful repentance. SIFF closed with Tsai Ming-liang's Goodby Dragon Inn (Taiwan). A wistful, elegiac tribute to a masterpiece of bygone cinema, King Hu's classic Dragon Inn (Hong Kong, 1968), it is as much a caustic farewell to an ornate theatre as a tip-of-the-hat to the martial arts genre pioneered by the Shaw Brothers in Hong Kong. Remarkable for its long takes and static shots, Goodbye Dragon Inn closes on a nostalgic note: two actors in the original, Tien Miao and Jun Shi, meet in front of the theatre to reminisce. They were practically the only spectators in the audience.

The festival's Special Focus on the Philippines featured a retrospective tribute to actress-director Laurice Guillen, who also served as president of the Silver Screen Awards jury. Another retro, "Shaw in Blue," focused on the erotic cinema of Li Han Hsiang and Chu Yuan, key figures in the rise of postwar Hong Kong cinema under the Shaw Brothers. Nuri Bilge Ceylan's Uzak (Distant, Turkey), awarded previously at Cannes, Istanbul, and Manila, was handed three more citations at Singapore (Best Film, Best Director, Best Actor, Mehmet Emin Toprak). Prasana Vithanage's Ira madiyama (August Sun, Sri Lanka), received the combined NETPAC-FIPRESCI Prize. Set in the mid-1990s, when the civil war in Sri Lanka was at its height, it depicts how three individuals struggle to recover what they have lost and are willing to risk everything for what really counts in life: a longing for identity, a sense of dignity, and a yearning to love and be loved.

\section{References}

\section{SILVER SCREEN AWARDS}

\section{ASIAN FEATURE FILM CATEGORY}

\section{Best Film}

Uzak (Distant, Turkey), Nuri Bilge Ceylan

\section{Best Director}

Nuri Bilge Ceylan, Uzak (Distant, Turkey)

Special Jury Prize

Vibrator (Japan), Ryuichi Hiroki 
Young Cinema Award

Panj é asr (At Five In The Afternoon, Iran), Samira Makhmalbaf

Best Actor

Mehmet Emin Toprak, Uzak (Distant, Turkey), dir Nuri Bilge Ceylan

Best Actress

Terashima Shinobu, Vibrator (Japan), dir Ryuichi Hirochi

NETPAC-FIPRESCI Award

Ira madiyama (August Sun, Sri Lanka), Prasanna Vithanage

\section{SINGAPORE SHORT FILM CATEGORY}

No Award for Best Film

Best Director

Students of CHIJ (Toa Payoh), Conflict and Crisis

Special Jury Prize - Special Achievement Award

Innocent, Gek Li San, Ho Choon Hiong

\section{Author Information}

Ron HOLLOWAY (1933-2009) was an American critic, film historian, filmmaker and correspondent who adopted Europe as his home in the early fifties and spent much of his life in Berlin. He was an expert on the study of German cinema and against all odds produced, with his wife Dorothea, the journal German Film, keeping us up-to-date with the work of directors, producers and writers and the showing of German films around the world.

In 2007, Ron Holloway and his wife were awarded the Berlinale Camera Award. Ron also received the Bundesverdienstkreuz (German Cross of Merit), Polish Rings, Cannes Gold Medaille, the American Cinema Foundation Award, the Diploma for Support of Russian Cinema and an honorary award from the German Film Critics' Association.

Ron was also a valued contributor to Kinema for the past fifteen years. 